\begin{tabular}{|c|c|c|c|c|c|c|c|}
\hline A & $\mathrm{R}$ & $\mathrm{T}$ & $\mathrm{I}$ & $\mathrm{C}$ & $\mathrm{L}$ & $\mathrm{E}$ & $\mathrm{S}$ \\
\hline \multicolumn{8}{|c|}{ ROCZNIKI PSYCHOLOGICZNE/ANNALS OF PSYCHOLOGY } \\
\hline
\end{tabular}

\author{
EWA SOKOŁOWSKA ${ }^{\mathrm{a}}$ \\ GRAŻYNA KATRA ${ }^{b}$

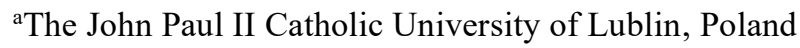 \\ Institute of Psychology

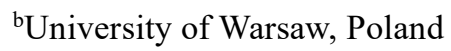 \\ Faculty of Psychology
}

\title{
A NEW APPROACH TO THE PROFESSIONAL ROLE OF THE SCHOOL PSYCHOLOGIST
}

\begin{abstract}
The article is an invitation to discuss the role and tasks of the psychologist in the modern school. It advances the thesis that the primary role of the psychologist is to co-create the school environment and the educational process. Being a co-creator is the essence of the presented model of the psychologist's work in the school system. The model covers psychological activities defined as monitoring promotion prevention, and intervention. It identifies the need to continually expand the possibilities of psychological influences and to create an autonomous vision of their realization. Adopting and performing this role in the way described in the model seems to be crucial to building the professional identity of the educational psychologist-and a well-defined and clarified professional identity is the basic regulator of a person's functioning in his/her professional role.
\end{abstract}

Keywords: school psychologist; promotion; prevention; psychological intervention; monitoring.

Ewa SoкоŁowsKa-The John Paul II Catholic University of Lublin, Institute of Psychology, Al. Racławickie 14, 20-950 Lublin, Poland; e-mail: ewasokolowska@kul.pl

GraŻYNA KATRA-University of Warsaw, Faculty of Psychology, Stawki 5/7, 00-183 Warsaw, Poland; e-mail: katra@psych.uw.edu.pl

The authors would like to acknowledge and to thank their colleagues Prof. Elżbieta Dryll, Anna Cierpka, PhD, DSc, and Małgorzata Babiuch-Hall, PhD, from the Faculty of Psychology, University of Warsaw, for their help in developing the monitoring-promotion-prevention-intervention model as well as to thank Małgorzata Bielen for translating this article. 


\section{INTRODUCTION: THE BASIC PRINCIPLES OF THE SCHOOL PSYCHOLOGIST'S WORK}

The main task of the school psychologist is to promote the development of children in the school environment (ISPA, 2011). This type of support and assistance also requires cooperation with the adults who bring up a child and/or are in his/her immediate as well as out-of-home environment. In order to ensure effective cooperation, the psychologist should adopt a partnership approach rather than a superior position.

It is also worth remembering that all undertakings and impacts resulting from the professional role of the school psychologist should comply with the code of ethics for this profession (APA, 2018; PTP, 1991) and the legal regulations relating to work in educational institutions in his/her country, which are not subject to negotiation and discussion, or to the guidelines formulated by the school psychologist's superiors or by psychologists working in psychological and educational counselling centers. The points that we consider the most important will be briefly discussed, with the proviso that all the rules are equivalent and that compliance with them is a prerequisite for the ethical fulfillment of the school psychologist's professional role.

The primary aim of the psychologist's work is to help other people deal with personal problems and achieve better quality of life. The first objective seems obvious and is widely shared. However, the second one is equally important. In the area of education, this means that the psychologist's work should not be limited merely to intervention and perhaps psycho-prevention, but should also include activities that aim to improve the quality of students' lives, for example by developing social skills, and to promote both children's and their educators' development and welfare. The presented approach can be considered innovative because it abandons a common strategy of conduct predominant in Polish schools - namely, the strategy of focusing on negative phenomena.

The basic ethical principle of the psychologist's work is confidentiality, which means that the client (i.e., the person under the psychologist's care) has the right to expect that the information the psychologist has about him/her is covered by professional secrecy. ${ }^{1}$ The psychologist cannot disclose it to other people without the consent of the person concerned, which also applies to a child, even the youngest one. Imparting information about the results of as-

\footnotetext{
${ }^{1}$ The exception to the rule of confidentiality is a situation of risk to life and health, of which the patient should be informed at the beginning of his/her contact with the psychologist (Bednarek, 2016; Brzeziński \& Toeplitz-Winiewska, 2004; Fiutak, 2016).
} 
sessment or about the course of a psychological conversation or therapy should be preceded by obtaining such consent. In practice, this means that a child must be consulted as to what information will be given to his/her parents andsubsequently, with the parents' consent - to the teachers or other people (e.g., a doctor). This requirement may seem unrealistic. Compliance with the principle of confidentiality is the highest manifestation of respect for the child, treated as a subject. This principle relates to the requirement of informing a child about assessment results and about the course of treatment work. The language of communication should be adapted to the child's abilities. However, when the psychologist gains the child's trust and convinces him/her that certain information will be passed on in order to improve the situation and help him/her solve the problems, there should be no trouble getting his/her approval for such action. When working with a small child, a psychologist can be permitted to give the parents - who are morally and legally responsible for their child - more extensive information; this refers, for example, to information resulting from the diagnosis, because it might be important for further assistance provided for the child.

Another important principle of the psychologist's work is to maintain professional independence. This means that, relying on his/her knowledge and competence as well as the ethical code, the psychologist decides for himself/herself and, in any case, makes the final decision and takes full responsibility for the actions taken in his/her professional capacity. In his/her professional activity, the psychologist adopts an internal perspective as a member of a given system or educational institution, and at the same time an external perspective as a person who is primarily concerned for the welfare of another human being, regardless of the targets set by this institution. What is at stake is the child's welfare, and the school psychologist is the child's spokesperson or an advocate for his/her welfare. The child - younger or older, or even a young adult —is, and should be, the center of the school psychologist's concern. Other people or different aspects of the developmental context (the environment) are important for the psychologist in so far as they constitute important factors in the proper and/or optimal functioning of the child. In this perspective, the school psychologist is not only at the school's service, engaged in its tasks and responding to the needs of the teaching staff, whose primary aim is to provide students with an education, but is also a co-creator of the school environment, understood as an environment in which the socialization and education of children and young people takes place (Sokołowska, Katra, Cierpka \& Turska, 2017). This approach is consistent with the principles adopted and promoted by the International School Psychology Association (ISPA, 2017). 
The school psychologist should cooperate with the child's guardians, such as parents and teachers, to the extent that is needed to provide him/her with proper conditions for development. This involves taking care of the climate prevailing in the school environment, whose quality is crucial to educational outcomes (Eccles \& Roeser, 2011; Katra, 2011; Laible \& Thompson, 2008; Laible, Thompson, \& Foirmson, 2016).

In the process of education and socialization, which, along with body maturation, determines the individual's personality and is crucial to what kind of person he/she becomes, it is impossible to disregard the values held in our culture. One of the most important values is recognizing the person's status as a subject and his/her right to develop her/her true potential, regardless of religion or ethnicity (APA, 2018). It is worth noting that humanity is born in relationships with others and the welfare of one individual ends where another person is harmed. In practice, reconciling the good of the individual and the good of others is not easy and often requires deeper reflection on the activities undertaken and on one's professional decisions - and it always requires an individual approach.

Education is a phenomenon whose essence is to prepare a dependent individual - the child - to live among and with others. This concept is accompanied by the assumption that education is basically an intentional process, undertaken by people who are socially appointed (delegated) to perform the role of the child's educators. In other words, being an educator constitutes an inseparable part of their professional role or social position. Undoubtedly, such a situation occurs in the family and in educational institutions, established to pursue educational objectives within the framework of the educational process, defined as "a process accompanying body maturation, occurring in the asymmetrical interaction between the teacher and the student and resulting in the mental development of the latter, mainly in social (developing social skills) and moral terms" (Sokołowska et al., 2017).

Thus defined, education should serve two functions: adaptive and emancipatory. The former prepares a student for being a person who adapts to society, while the second helps him/her to be an independent, responsible, and creative person. In our opinion, they are not in opposition but complement each other. It is easier, however, to see irregularities in how the adaptive function is carried out in the educational process than to see them in performance of the emancipatory function, which is becoming extremely important nowadays. The individual should be prepared to take autonomous decisions and construct his/her life with and among other people, in a specific community and culture. In order to take up life's challenges, a person has to know the moral and social rules and have the 
necessary skills (reflexivity, critical thinking), which he or she must use creatively and/or modify in order to maintain balance between fulfilling his/her own needs and potential on the one hand and the good of the community and other people on the other. Nowadays, on the basis of positive psychology, the psychology of resilience (Ostrowski, 2015; Ostrowski, Sikorska, \& Gerc, 2015; Richardson, 2002; Sikorska, 2016; Wolfe, 2014), and an approach focused on solutions (Świtek, 2014), experts highlight not only the role of individuality but also social resources and good social relations as essential for well-being and proper functioning (UNICEF, 2017). Striving for friendly and supportive relations with others requires not only the ability to ask for help and put it to good use, but also giving support as well as showing concern and understanding for others. It underlies social skills, well-being, and the sense of meaning in life. It should also inspire educators involved in the upbringing process (Eggerman \& Panter-Brick, 2010).

From the perspective of the effects of education, it is important for educators to realize that a child learns by observing other people's behavior and that it is educators who are the most important models for their charges (Bandura, 1997). Therefore, they should not limit their perception of the upbringing process only to the intentional educational measures that they consciously undertake. They should be fully aware that they are "carriers" of specific patterns of behavior which children - students - follow, both intentionally and unintentionally. Education cannot be perceived merely as deliberate and conscious efforts on the part of educators, targeted at students. What is needed is a broad ecological approach to this process; what this means for the educational psychologist is dealing not only with the child's/student's development but also with the environment (e.g., the school climate) in which the child grows up.

Given the assumptions and approach to education outlined above, in this article we want to present a model of the school (educational) psychologist's work which we have proposed as the M-P-P-I (Monitoring-Promotion-PreventionIntervention) model (Katra \& Sokołowska, 2010). The model includes psychological activities categorized as monitoring, promotion, prevention, and intervention. It should be noted that the M-P-P-I model is a formal and intercultural one. It is a kind of framework to be filled with contents that are culturally determined or that take account of current conditions and circumstances. An example can be the issue of respect for the rights of the child (ISPA, 2011, 2017). These rights should be promoted, preventive actions should be taken to stop them from being violated, and if they are, intervention should be made. 


\section{DESCRIPTION OF THE FOUR-ELEMENT M-P-P-I MODEL, WITH EXAMPLES}

The first category of activities we present is monitoring. It is a necessary complement to the pyramid in our model of the school psychologist's work (see Figure 1).

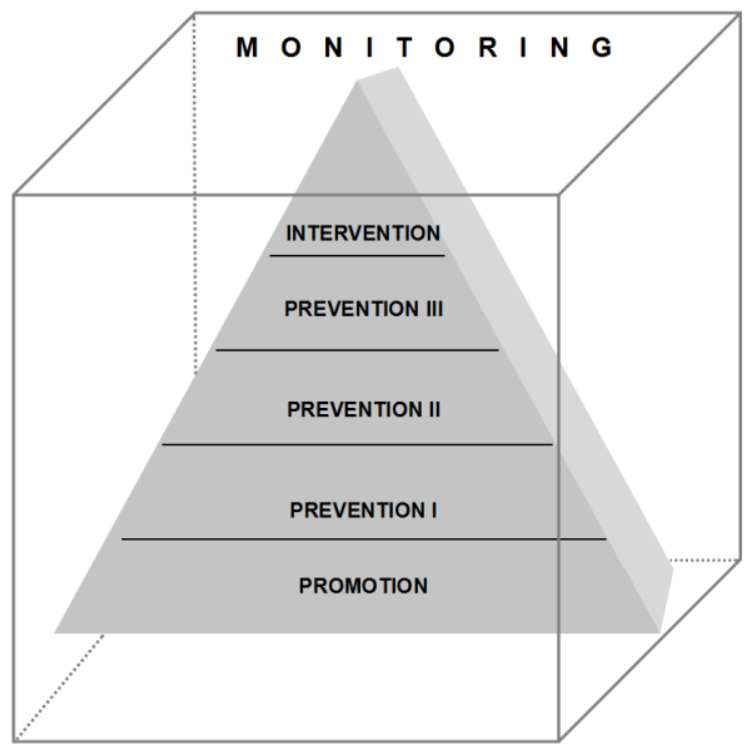

Figure 1. The M-P-P-I model as a pyramid, with promotion as the base and with successive forms of activities placed in the space of monitoring.

Monitoring is the base for the remaining categories of action; before taking them, the educator must observe school life from the perspective of the educational process and keep track of how the basic educational functions (adaptive and emancipatory) are performed. The essence of monitoring is, therefore, to observe the course of the educational process. This involves observing to what extent the child has a chance to assimilate moral norms and acquire social skills along with developing his/her individuality and potential as well as building self-reliance and responsibility for his/her functioning. The primary function of this psychological activity is to control the educational process and the child's development, taking place within the framework of promotion, psycho-prevention, and intervention. 
Monitoring also consists in regularly watching or checking the effectiveness of various actions undertaken within the framework of promotion, prevention, and intervention. It can be defined as a category of activities continuously undertaken in school, simultaneously with other kinds of psychological activities. The education and upbringing process requires control and reflection from the school psychologist. He/she needs to look through the prism of objectives other than those formulated by the educational system.

The forms of monitoring are: observation of individuals and groups, conversation and psychological interview conducted during meetings with classes and teachers, surveys and questionnaires carried out among students and other participants in school life that allow for gathering information, a monograph on a class, ${ }^{2}$ or sociometric research defining the position of an individual in the group and the character of ongoing interaction. The most complex form of monitoring and/or its culmination is expert evaluation of the education system (Jurkowski, 2003).

Promotion, another category of activities included in the M-P-P-I model, is essential for the presented model of the educational psychologist's work in school. In our opinion, the ultimate aim of the school psychologist's work is to support an individual in achieving a better quality of life. A person attains psychophysical well-being when he/she is able to experience life as meaningful, has the feeling that he/she is creative and productive, and copes effectively with challenges. According to WHO, these are the criteria which are met by a healthy person (WHO, 2001). Physical and mental well-being, maintaining satisfying interpersonal relationships, solving problems in a constructive way (including developmental tasks), a positive quality of life, and a sense of happiness are fundamental aspects of positive psychology, which is sometimes referred to as a theoretical framework of promotion. ${ }^{3}$

\footnotetext{
2 The method devised by Antonina Gurycka (1982), which consists in gathering information about a specific class and its students on several levels, from the individual level (basic and demographic information about students and their state of health) to information about the class as a social group (positions occupied in the class by individual students, the popularity of individual children, etc.), highlighting the role of the teacher as the leader of this group (the way of managing the class, overt and hidden conflicts, etc.).

${ }^{3}$ Examples of mental health models that draw on positive psychology resources are: the functional model of mental health (Lehtinen, 2008); the model of complete health (Keyes \& Lopez, 2002), and the salutogenic model (Antonovsky, 1987). Individual and environmental resources can serve a protective function, enhancing positive mental health. High psychological, emotional, and social well-being manifests itself, among other things, in taking care of others, in high self-esteem, in a positive and balanced mood, and in a sense of coherence (Czabała, 2015). People with a good sense of coherence are aware that they have a strong sense of understanding of incoming infor-
} 
The rationale for this approach is the fact that the psychologist not only reacts to somebody's personal problems by helping to solve them but also co-creates - in a thoughtful manner - the educational environment, together with other people who are responsible for the students' development (parents, teachers, psychologists, and educators). Our model psychological work diverges from standard practice, since the percentage of time and the amount of effort put in by psychologists - on account of the requirements laid down in schools nowadaysrefer mainly to assessment, crisis intervention, as well as prevention of mental problems and school failure. Promotion may relate not only to learning processes (see NASP, 2010) but also to the processes of shaping personality, which means supporting the individual's positive characteristics ${ }^{4}$ (Sokołowska, ZabłockaŻytka, Kluczyńska, \& Wojda-Kornacka, 2015, 2016). This is consistent with the theoretical and practical requirements applied in psychology in situations when psychological support is provided (Standards of Practice for Health Promotion in Higher Education, cited in: ACHA, 2012; WHO, 2002, 2005), with the ethical standards, and with participants' expectations as to the nature of a specific promotion. Promotion can include training in attitudes and skills such as rational thinking, focusing on the positive sides of everyday life, recognizing one's true potential and strengths, communicating in a direct way, resolving disputes in a constructive way, time management, and learning methods involving self-affirmation (e.g., "I know," "I can," "I will manage") as well as inspiring positive and adequate emotions (see Cottrell, 2003; Hartley, 2002; Hayes \& Smith, 2005; Miskimin \& Stewart, 2011).

An example of school promotion may be the entire school and class security system implemented in a given institution (see Kołakowski, 2013, pp. 406-429). The rules are regarded as an essential element of education. They are publicized and discussed. All the staff and students refer to them in the daily life of the

mation. They are characterized by a sense of resourcefulness, which means that they realize they have the resources to meet demands, and by a sense of reasonableness, i.e. the belief that it is worthwhile to be involved and that problems are a challenge rather than an insurmountable obstacle (Antonovsky, 1987).

${ }^{4}$ In the three research projects, positively evaluated by the ethics committee, we investigated young adults' expectations concerning mental health promotion (see Sokołowska et al., 2016) and planned the contents of promotion program that could be implemented in schools and/or universities (Sokołowska et al., 2015). Among other things, we planned in detail to support individuals' positive characteristics, namely the realization of their strengths, the visualization of their positive plans and expectations for the future, and focus on the successes of everyday life and on activities that inspire positive emotions (see the exercises called "I and my resources," "Visualization of the future-a diary of the future," "Successes," and "Pleasure planning," cited in Sokołowska et al., 2015, pp. 136-141). 
school, which is a good practice. Everybody knows what is positive and indicates concern for others (prosocial behavior is expected) and what standards of behavior are required. This facilitates interactions between the teachers and students and between the teachers and parents. One element of this system is the "Code of anger," which assumes that there are acceptable and unacceptable ways of expressing anger. For example, it is forbidden to "hit anyone, including myself" or "scatter things around the classroom," but it is not forbidden to "say aloud what I feel and why" or "ask if I can go out of the classroom to calm down" (postscript added by the authors of the article: for security reasons, the last method applies only to "almost adult" students) (Kołakowski, 2013, p. 419). Everyone has the right to be angry, but breaking the rules results in certain unpleasant consequences. This kind of promotion includes any activity that allows people to build a good school climate and which ensures that the transparency and predictability of the school environment as well as positive attitude towards individual subsystems in the school and towards one another are respected and supported.

Another important element of promotion is care about the quality of relationships. Our school should be a community of people who support and respect one another and resolve conflicts constructively - or, in any case, do their best. The role of the psychologist would be to model an attitude of mutual respect and understanding, acknowledging the rights of the individual. For example, he/she could organize workshops on communication, conflict resolution, negotiation, self-regulation, or integration activities. The following projects are examples of integration activities: "Youth for Hospice," "The Invisible Hand (Pass Good On)," "Winter and Birds," "Holidays With Poetry," "Summer Play Academy," "The Painting Picnic," or "Idyllic Climates" (see "Project as a Method of Educational Work," in Kołakowski, 2013, pp 558-573). It is noteworthy that these projects were planned together with the students and that the whole community benefited from them, not just students - the beneficiaries of such activities are often the elderly, the sick, those in need of learning support, and many others.

Another useful promotional activity could be organizing a psychology club, conducted by a psychologist in the school for all interested students. In this kind of club, students could have an opportunity to familiarize themselves with the latest psychological knowledge (e.g., learn about the models and concepts of mind functioning), and with the methods of training in important mental functions (e.g., mastering memory strategies or developing emotional intelligence). Besides, they could get to know each other and have an opportunity to consolidate the school community (initiatives such as voluntary work, integration days, the or psychologist's days). 
The aim of school promotion is to create optimal conditions for the students' personal growth by developing their individual resources, building systems of mutual support, as well as improving the school environment (school climate) so that each person individually and all the people together can receive support. Last but not least, promotion should aim at acquiring competence in proactive self-regulation ${ }^{5}$ (Katra, 2011, 2016).

The function of promotion can be defined as developing the child's abilities, providing positive role models, improving interpersonal skills, as well as increasing the child' and his/her teachers' well-being. The form of the work used in promotion does not differ from the methods employed in other psychological activities. These are, for example, active methods such as workshops, coaching, training, and lectures. The participants may be assigned homework, to be done either on paper or in an electronic form. They have access to audiovisual materials.

In the presented $\mathrm{M}-\mathrm{P}-\mathrm{P}-\mathrm{I}$ model, prevention is the third element, placed immediately next to promotion. In this theoretical model it is a natural continuation of promotion. In definitional terms, the difference between prevention and promotions lies in the fact that the former focuses on threats and possible psychological problems and difficulties, which means preventing risky behavior or irregularities in the educational process. Breaking prevention down into three categories - primary, secondary, and tertiary - makes sense if we take account of the situation in a specific school. Working with groups of children and adolescents, when adverse events still have not occurred, or if they have, they have not set in yet (primary and secondary prevention), will be completely different than working in a school where such events have already taken place, required intervention, which was effective, and after it has been successfully completed, the person (people) who is (are) still recovering is (are) back under the care of the school psychologist. Then we smoothly enter the third, "preventive" phase (aid), which is to ensure that the person (people) will not resort to the earlier unfavorable methods of resolving difficult situations.

An example of school prevention is prevention programs, which are designed to last a few weeks, up to several months. A model method in the case of primary

\footnotetext{
${ }^{5}$ Proactive self-regulation means conscious realization of intents and purposes, in both near future and distant future. It is a process which consists of four phases: (1) pre-decision-making (transposition of needs and desires into intentions and choosing related goals), (2) pre-activity (adopting ready-made strategies to achieve goals or devising a plan of action), (3) activities (implementing and monitoring a plan), and (4) post-activity (reflection on the result obtained) (Katra, 2011, 2016; Zimmerman, 1990, 2002; Zimmerman \& Schunk, 2004).
} 
prevention could be the actuarial method of supporting mathematical thinking in children called „Children's Mathematics,” developed by Edyta GruszczykKolczyńska ${ }^{6}$ and addressed to children who start their mathematical education in school (Gruszczyk-Kolczyńska \& Zielinska, 2009). The Good Start Method (GSM, Bogdanowicz, 2014), based on the method of Le Bon Départ ${ }^{7}$ (LBD), has a similar character). ${ }^{8}$ It is another method addressed to children who start writing. These programs were created for Polish pupils in order to prevent school failure, and there are documented reports that they work well in primary schools.

Secondary (selective) prevention is addressed to people in the risk group. In most cases, these are students who experience a specific difficulty, but one that is not fixed, so it does not require intervention (including crisis intervention) as yet. Thus, it is clear that the aim is to prevent a specific negative developmental phenomenon from intensifying or becoming fixed. When the need arises, a psychologist "invites" a selected student—selected as the one who needs help the most - to a special meeting, together with a person who supports him/her. Teacher and parent modules, addressed directly to adults, are included in all known cognitive behavioral programs for children at risk of behavioral disorders (Bloomquist, 2006; Bywater \& Eames, 2007; Bywater, Hutchings, Judith, Gridley, \& Jones, 2011; Hutchings et al., 2011; Jones, Daley, Hutchings, Larson, \& Lochman, 2011; Manby, 2005; Webster-Stratton, Reid, \& Stoolmiller, 2008) or emotional disorders (Kendall \& Hedtke, 2013a, 2013b). They can be defined as programs that prevent educational problems and difficulties (Kołakowski, 2013). Secondary prevention programs are focused on specific psychological problems or difficulties - for example, on how to deal with the negative effects of stress,

\footnotetext{
${ }^{6}$ Most of the studies published by the author and her team are in Polish, as they are addressed to specialists working with Polish students and suggest specific methods of work useful for parents, teachers, or students. The article cites only one Polish title, chosen as an example of dozens of other studies. However, to introduce the author's intents and purposes, we provide the address of the website in English that has been developed by the author herself (Gruszczyk-Kolczyńska, 2016) and an English review of one of her works which focuses on the program of 2012 (Szewczuk, 2013).

7 "Le Bon Départ is a form of psychomotor therapy in which music and rhythm play a prominent role. The method was originally developed by Thea Bugnet as an educational method for toddlers to prepare them for writing education. To date, the LBD is also used as a treatment for developmentally delayed children in the Netherlands, Belgium, France, Portugal, Spain, Switzerland and Poland" (see Leemrijse, Meijer, Vermeer, Adèr, \& Diemel, 2000, p. 248).

${ }^{8}$ Studies by the Bogdanowicz team are mainly in Polish because they provide source materials and detailed step-by-step instructions for parents, teachers, and even students on how to work (see Bogdanowicz, 2014). In order to introduce the methodology used for this method, we present its application in teaching English to Polish children, because the study refers to the MDS rules (see Bogdanowicz \& Bogdanowicz, 2016).
} 
how to respond to aggression, how to refuse to take drugs, or how to effectively avoid substance abuse.

The most difficult thing to implement in school is tertiary (indicative) prevention, as it is addressed to people who have experienced difficulties, received psychological help, and are now recovering, but we want to make sure that these disorders will not appear again after the person returns to school and to the environment where they live. Tertiary prevention primarily means supporting the therapeutic or rehabilitation processes conducted outside the school.

The basic principle behind the development of prevention programs is that prevention is better than cure. Picking up and responding to signs of difficulty by giving rules about how to deal with problems (discussing the rules of communicating without violence, four-step assertive reaction, communicating the self, etc.) and improving coping skills seems appropriate and useful and is the primary aim of prevention. The essential aim of preventive activities in schools is to avoid specified negative phenomena related to students' education or behavior that might adversely affect the student's development. The function of school prevention is to increase the teachers' competences, develop students' interpersonal skills, build up their resistance to unfavorable environmental influences, and enhance self-regulation.

The basic forms of prevention are largely similar to the forms of promotion: lectures, instructions, and talks on education and development; the difference is that prevention focuses on correcting mistakes, whereas promotion is focused on development. The active forms are also alike: coaching, workshops, and training courses that combine theory and practice.

Intervention is the moment in the school life when the psychologist has to offer treatment to a child or a young person, provide help in solving specific problems, and directly respond to the difficulties and problems faced by the students as well as the adults who support them. Apart from mental disorders, there is a whole range of problems calling for intervention. The examples of risky behavior include skipping classes, suspending the student's rights, and having premature intercourse or sex without protection. These types of behavior are regarded as risky because they increase the likelihood of adverse psychological, social, and health impacts on the child's development. In times of crisis, intervention should be undertaken within 72 hours, without undue delay (preferably straightaway). Crisis intervention requires a great mobilization of the communitybacking up the existing support network or seeking assistance from the immediate environment and volunteers (James \& Gilliland, 2007). There are specific procedures for responding, for example, to a terrorist attack at school, a natural 
disaster, or a fatal accident, which can all be traumatic experiences (if the experience is not worked through, the result might include the occurrence of PTSD in a student). Intervention is closely associated with the psychologist's work. When something is wrong, it seems to be absolutely essential and is regarded as a natural psychological situation. Contacting the psychologist is then described exclusively as a helping (therapeutic/healing) relationship. The novelty of the model presented in the article lies in giving students a sense of naturalness in their contact with the psychologist well in advance, before problems that cannot be solved without professional help arise-before there is any talk about difficulties cropping up. The psychologist in M-P-P-I model does not work only as an "ambulance" or the "GP." When there seems to be no way out, when the person has given up because his/her ways of remedying the situation have proved inadequate, it is even more difficult to overcome his/her fear and distrust. Trust in the psychologist can also be built in everyday relations, when assistance is not sought, but students enjoy the opportunity to learn about themselves and others. Thanks to what they have learned, in a difficult or even traumatic situation, they do not have to break down barriers and negotiate with themselves if perhaps the time has come when there is no way out but accept the psychologist's help.

The article presents a model of cooperation between the psychologist and the school in which intervention takes up a small percentage of the psychologist's time and is provided for a small percentage of the student population. Solving problems on a regular basis would facilitate the psychologist's work, as he/she would not have to work intensively with a particular person or a group of students. It would provide plenty of daily opportunities to use his/her psychological knowledge, test his/her skills, and-step by step—build up personal skills.

An example of intervention is the procedure to follow in the event of an incident of aggression. Each procedure is based on certain assumptions. Crisis (urgent) intervention can be divided into the following stages: (a) assistance in dealing with emotions (reducing emotional chaos, fear and suffering, enabling the client to express and abreact emotions), (b) assistance in obtaining a new perspective on the crisis, its importance and consequences, and (c) devising a plan and monitoring the process of solving the crisis (working out new, effective methods for dealing with the root problems of the crisis) (as presented in James \& Gilliland, 2007).

The essence of intervention is to correct irregularities in the process of child development or upbringing. The basic function of intervention is to restore the balance, to rectify upbringing errors, and to correct or compensate for negative upbringing experiences or developmental pathology. It can take the form of 
advice for parents or teachers, or of direct help given to a child in dealing with problematic behavior or learning difficulties.

\section{IMPLICATIONS FOR SCHOOL HEALTH}

Apart from providing a formal framework for discussing the role of the school psychologist, the presented M-P-P-I model aspires to become a theoretical basis for this role and for the formation of professional identity. It could even be referred to as a "philosophical" model. The response given by a specialist to the question: Who am I as a psychologist? might include references to "finding fulfillment" in the aforementioned activities. There is much confusion as to the scope of the school psychologist's duties, which the M-P-P-I model could dispel. By organizing his/her work according to the presented model, the psychologist has the opportunity to invite those people who are the most important for a child to cooperate. He/she can also determine exactly what his/her work will involve. The truth of the matter is that without this systemic support the psychologist will not achieve much.

The M-P-P-I model emphasizes the creative aspect of the role of the school, or, more broadly, of the educational psychologist (with the proviso that not every educational psychologist works in a school). He/she is a co-creator of the school environment, that is a person who, together with the teachers and the management, organizes work in the school and makes sure that its educational tasks are fulfilled and that the students' proper development is fostered.

We understand and define the educational process as a phenomenon conditioned by various influences, including indirect influences coming from the "higher order" environments in which the school and its students are immersed. According to the presented model, however, the school psychologist has the greatest scope for action and understands that the style of the school's functioning and its climate play an important role in the process of education and upbringing and contribute to - or interfere with - the effectiveness of these actions. Our model may be useful not only for school psychologists, but also for teachers and parents - that is, educators who are aware of their social mission.

In the final part of the article, we will present the functions of the model more specifically, indicating how it might be useful. Firstly, the model determines the direction of work and allows the psychologist to monitor his/her activities in a methodical and systematic way. Furthermore, it might be helpful in realizing professional challenges and in formulating tasks to be performed as part 
of his/her job. Moreover, it allows for constructing more realistic social expectations from psychologists and educational institutions. Its use might also include designing psychologists' professional development as well as providing school and educational psychologists with a framework for establishing their professional identity. Finally, it should be treated as inspiration for further efforts, focused on determining the role of the school psychologist in the education system and educational institutions.

In summary, the model defines the scope and nature of the necessary yet basic competences which the school psychologist should have. This does not mean that all of these competences must be or are highly developed in a particular person. Some psychologists can perfectly cope with crisis situations, while others are skillful in handling conflicts. However, every school psychologist should have some basic knowledge and the skills described above (see NASP, 2010). On the other hand, he/she should be able to collaborate with other professionals in the process of upbringing and education, primarily with teachers, parents, and other psychologists, or with doctors when the situation requires it. $\mathrm{He} /$ she should support parents and teachers in their efforts, because it is parents and teachers who have a direct and permanent impact on the child's development.

The school psychologist's work might also be of a direct character, but is always limited in time. The psychologist plays a secondary role in the child's life and this state/relationship should remain so (i.e., unchanged), no matter how intense the work with the child is. The psychologist should always keep in mind that the top priority is the child's relationship with his/her parents as well as his/her good relationships at school, as it is where his/her "real" life takes place.

We must not forget that the school psychologist has also an indirect influence on the child. This happens through cooperation with the child's parents and teachers, sometimes with the school support staff, or even with the local community, as well as through cooperation in designing curricula and educational programs in educational institutions.

An indirect impact on the child is exerted by the climate prevailing in the school or any other educational institution as well as the climate in the family. Current studies on socialization show that tender loving care given to children makes them more susceptible to educational influences; kids eagerly obey their teachers and try to "ingratiate themselves" with the latter by assimilating the accepted moral standards and manners. At the same time, they become more confident and ready to cooperate with others. Thus, the importance of promotion cannot be overestimated. The holistic M-P-P-I model has practical significance. 
It seems useful for defining the nature of the psychologist's work, for ensuring the quality of support provided to the child, or for devoting time to specific activities in order to achieve the optimum effects of the educational process.

\section{REFERENCES}

ACHA [American College Health Association] (2012). Standards of practice for health promotion in higher education. Retrieved from https://www.acha.org/documents/resources/guidelines/ ACHA_Standards_of_Practice_for_Health_Promotion_in_Higher_Education_May2012.pdf

Antonovsky, A. (1987). Unraveling the mystery of health. How people manage stress and stay well. San Francisco, CA, US: Jossey-Bass.

APA [American Psychological Association] (2018). Ethical principles of psychologists and code of conduct. Retrieved from https://www.apa.org/ethics/code/principles.pdf. Published June 1, 2003. Accessed February 1, 2018.

Bandura, A. (1997). Self-efficacy: The exercise of control. New York, NY, US: W H. Freeman.

Bednarek, D. (2016). Zawód psycholog. Regulacje prawne i etyka zawodowa [Occupation: Psychologist. Legal regulations and professional ethics]. Warsaw, Poland: Wydawnictwo Naukowe PWN.

Bloomquist, M. L. (2006). Skills training for children with behavior problems. Revised edition: A parent and practitioner guidebook. New York, NY, US: Guilford Press.

Bogdanowicz, M. (2014). Metoda Dobrego Startu we wspomaganiu rozwoju, edukacji i terapii pedagogicznej [The Good Start Method in supporting development, education, and pedagogical therapy]. Gdańsk: Harmonia Universalis.

Bogdanowicz, K. M., \& Bogdanowicz, M. (2016). "The Good Start Method for English” or how to support development, prevent and treat risk of dyslexia in children learning English as a second language. Polish Psychological Bulletin, 47(3), 265-269. doi: 10.1515/ppb-2016-0032

Brzeziński, J., \& Toeplitz-Winiewska, M. (Eds.) (2004). Etyczne dylematy psychologii [Ethical dilemmas of psychology]. Warsaw, Poland: Academica Wydawnictwo SWPS.

Bywater, T., Hutchings, J., Judith, M., Gridley, N., \& Jones, K. (2011). Incredible Years parent training support for nursery staff working within a disadvantaged flying start area in Wales: A feasibility study. Child Care in Practice, 7, 285-302. doi: http://dx.doi.org/10.1080/1357 5279.2011 .575353

Cottrell, S. (2003). The study skills handbook (Palgrave Study Guides). Basingstoke, UK: Palgrave Macmillan.

Czabała, J. Cz. (2015). Poradnictwo psychologiczne [Psychological counseling]. In J. Cz. Czabała \& S. Kluczyńska (Eds.), Poradnictwo psychologiczne [Psychological counseling] (pp. 16-44). Warsaw, Poland: Wydawnictwo Naukowe PWN.

Eccles, J. S., \& Roeser, R. W. (2011). Schools as developmental contexts during adolescence. Journal of Research on Adolescence, 21(1), 225-241. doi: 10.1111/j.1532-7795.2010.00725.x

Eggerman, M., \& Panter-Brick, C. (2010). Suffering, hope, and entrapment: Resilience and cultural values in Afghanistan. Social Science \& Medicine, 71(1-2), 71-83. doi: 10.1016/ j.socscimed.2010.03.023. Retrieved from https://www.ncbi.nlm.nih.gov/pmc/articles/PMC3 $125115 /$ 
Fiutak, A. (2016). Pomoc psychologiczna. Prawo i etyka $w$ zawodach terapeuty i psychiatry. [Psychological support. Law and ethics in the professions of the therapist and psychiatrist]. Warsaw, Poland: Difin.

Gruszczyk-Kolczyńska, E. (2016). Recognizing mathematically gifted children and assisting their development at home, in kindergarten and school. Retrieved from http://www.cme.rzeszow. $\mathrm{pl} /$ index.php? $\mathrm{p}=2010 / \mathrm{ch} 3-6 \_10$

Gruszczyk-Kolczyńska, E., \& Zielińska, E. (2009). Zajęcia dydaktyczno-wyrównawcze dla dzieci, które rozpoczna naukę $w$ szkole. Podstawy psychologiczne i pedagogiczne oraz zabawy $i$ sytuacje zadaniowe sprzyjajace wspomaganiu rozwoju umystowego i kształtowaniu waznych umiejętności [Compensatory classes for children who begin school. The psychological and pedagogical basics as well as games and task situations conducive to supporting mental development and acquiring important skills]. Warsaw, Poland: Edukacja Polska.

Gurycka, A. (1982). Monografia klasy. Metoda badań psychopedagogicznych [Monograph on a class. The psychopedagogical research method]. Psychologia Wychowawcza, 2, 145-155.

Hayes, S. C., \& Smith, S. (2005). Get out of your mind and into your life. Oakland, CA, US: New Harbinger Publications.

Hutchings, J., Bywater, T., Williams, M. E., Whitaker, Ch., Lane, E., \& Shakespeare, K. (2011). The extended school aged Incredible Years parent programme. Child and Adolescent Mental Health, 16, 136-143. doi: 10.1111/j.1475-3588.2010.00590.x.

ISPA [International School Psychology Association] (2011). ISPA Code of Ethics. Retrieved from http://www.ispaweb.org/wp-content/uploads/2013/01/The_ISPA_Code_of_Ethics_2011.pdf

ISPA [International School Psychology Association] (2017). ISPA Award for Outstanding International School Psychology Practice. Retrieved from http://www.ispaweb.org/about-ispa/ispaawards/the-ispa-award-for-outstanding-international-school-psychology-practice/

James, R. K., \& Gilliland, B. E. (2007). Crisis intervention strategies. Belmont, CA, US: Thomson Brooks/Cole.

Jones, K., Daley, D., Hutchings, J., Bywater T., \& Eames, C. (2007). Efficacy of the Incredible Years Basic parent training. Child: Care, Health and Development, 33(6), 749-756. doi:10.1111/j.1365-2214.2008.00817.x

Jurkowski, A. (2003). Specyfika i znaczenie społeczne psychologii wychowawczej [The characteristics and social significance of educational psychology]. In A. Jurkowski (Ed.), Z zagadnień wspótczesnej psychologii wychowawczej [Selected issues of contemporary educational psychology] (pp. 12-26). Warsaw, Poland: Wydawnictwo Instytutu Psychologii PAN.

Katra, G. (2011). The cultural context of adolescents' life plans in the age of globalization. Life plans of Chinese and Polish adolescents. In B. Kaczmarek, G. Kwiatkowska, \& K. Markiewicz (Eds.), Youth facing the challengers of globalization (pp. 173-182). Lublin: Wydawnictwo Uniwersytetu Marii Curie-Skłodowskiej.

Katra, G. (2016). Supporting the adolescents prospective activity. In U. Tokarska (Ed.), Applied psychology of time (pp. 181-211). Warsaw, Poland: Wydawnictwo Naukowe PWN.

Katra, G., \& Sokołowska, E. (Eds.) (2010). Rola i zadania psychologa we współczesnej szkole [Psychologist's role and tasks in contemporary schools]. Warsaw, Poland: Wolters Kluwer, Wydawnictwo Fraszka Edukacyjna.

Kendall, Ph. C., \& Hedtke, K. A. (2013a). Terapia poznawczo-behawioralna zaburzeń lękowych $u$ dzieci. Podręcznik terapeuty. Program lęk [Cognitive-behavioral therapy for anxious children: Therapist manual. Coping Cat. Translation: Ćwiklińska-Zaborowicz Anna, 
de Flassilier-Popławska Joanna, Kiełtyka-Czech Monika]. Sopot, Poland: Gdańskie Wydawnictwo Psychologiczne.

Kendall, Ph. C., \& Hedtke, K. A. (2013b). Terapia poznawczo-behawioralna zaburzeń lękowych u dzieci. Zeszyt ćwiczeń. Program lęk [Cognitive-behavioral therapy for anxious children: The Coping Cat workbook. Translation: Ćwiklińska-Zaborowicz Anna, de Flassilier-Popławska Joanna, Kiełtyka-Czech Monika]. Sopot, Poland: Gdańskie Wydawnictwo Psychologiczne.

Keyes, C. L. M., \& Lopez, S. (2002). Toward a science of mental health: Positive direction in diagnosis and interventions. In C. R. Snyder \& S. J. Lopez (Eds.), The handbook of positive psychology (pp. 26-44). New York, NY, US: Oxford University Press.

Kołakowski, A. (Ed.) (2013). Zaburzenia zachowania u dzieci. Teoria i praktyka [Behavioral disorders in children. Theory and practice]. Sopot, Poland: Gdańskie Wydawnictwo Psychologiczne.

Laible, D., \& Thompson, R. A. (2008). Early socialization: A relationship perspective. In J. E. Grusec \& P. D. Hastings (Eds.), Handbook of socialization. Theory and research (pp. 181-207). New York, NY, US: The Guilford Press.

Laible, D., Thompson, R. A., \& Foirmson, J. (2016). Early socialization: The influence of close relationships. In J. E. Grusec \& P. D. Hastings (Eds.), Handbook of socialization. Theory and research (pp. 35-59). New York, NY, US: The Guilford Press.

Larson, J., \& Lochman, J. E. (2011). Helping schoolchildren cope with anger. A cognitive behavioral intervention. New York, NY, US: The Guilford Press.

Leemrijse, Ch., Meijer, O. G., Vermeer, A., Adèr, H. J., \& Diemel, S. (2000). The efficacy of Le Bon Départ and Sensory Integration treatment for children with developmental coordination disorder: A randomized study with six single cases. Clinical Rehabilitation, 14, 247-259. doi:10.1191/026921500674930367

Lehtinen, V. (2008). Building up good mental health. Jyväskylä: Stakes Gummerus Printing.

Manby, M. (2005). Evaluation of the impact of the Webster-Stratton Parent-Child Videotape series on participants in a Midlands town in 2001-2002. Children \& Society, 19, 316-328.

Miskimin, D., \& Stewart, J. (2011). Coaching rodzicielski. Jak pomóc swojemu dziecku rozwinąć skrzydła i w pełni realizować jego potencjał [The coaching parent: Help your children realise their potential by becoming their personal success coach]. Warsaw, Poland: Academica, Wydawnictwo SWPS.

NASP [National Association of School Psychologists] (2010). The National Association of School Psychologists model for comprehensive and integrated school psychological services. School Psychology Review, 39, 320-333.

Ostrowski, T. M. (2015). Resiliency and the meaning of life. In T. M. Ostrowski, I. Sikorska, \& K. Gerc (Eds.), Resilience and health in a fast-changing world (pp. 19-31). Cracow, Poland: Wydawnictwo Uniwersytetu Jagiellońskiego.

Ostrowski, T. M., Sikorska, I., \& Gerc, K. (2015). Resilience from a variety of theoretical perspectives: An introduction. In T. M. Ostrowski, I. Sikorska, \& K. Gerc (Eds.), Resilience and health in a fast-changing world (pp. 7-15). Cracow, Poland: Wydawnictwo Uniwersytetu Jagiellońskiego.

PTP [Polish Psychological Association] (1991). Kodeks Etyczny Polskiego Towarzystwa Psychologicznego [Polish Psychological Association Code of Ethics]. Retrieved from http://www.ptp.org.pl/modules.php?name=News\&file=article\&sid=29

Richardson, G. E. (2002). The metatheory of relisience and resiliency. Journal of Clinical Psychology, 58, 307-321. 
Sikorska, I. (2016). Odporność psychiczna $w$ okresie dzieciństwa [Resilience in childhood]. Cracow, Poland: Wydawnictwo Uniwersytetu Jagiellońskiego.

Sokołowska, E., Katra, G., Cierpka, A., \& Turska, D. (2017). Psycholog jako współkreator środowiska i procesu edukacyjno-wychowawczego [The psychologist as a co-creator of the educational environment and the educational process]. Psychologia Rozwojowa, 22(2), 33-44. doi: 10.4467/20843879PR.17.008.7040

Sokołowska, E., Zabłocka-Żytka, L., Kluczyńska, S., \& Wojda-Kornacka, J. (2015). Zdrowie psychiczne młodych dorostych. Wybrane zagadnienia [Mental health of young adults. Selected problems]. Warsaw, Poland: Difin.

Sokołowska, E., Zabłocka-Żytka, L., Kluczyńska, S., \& Wojda-Kornacka, J. (2016). What mental health promotion do university students need? Polish Journal of Applied Psychology, 14(3), 53-72. doi: 10.1515/pjap-2015-0062

Szewczuk, K. (2013). [Review of the book About children with mathematical skills. A book for parents and teachers, ed. E. Gruszczyk-Kolczyńska]. Journal of Preschool and Elementary School Education, 2, 125-129.

Świtek, T. (2014). The situations focused model: A map of solution-focused brief therapy used as an open systems approach with clients and in human services. International Journal of Solution-Focused Practices, 2, 40-51.

UNICEF [United Nations International Children's Emergency Fund] (2017). UNICEF's Strategy for Health (2016-2030). UNICEF Programme Division. Retrieved from https://www.unicef. org/health/files/UNICEF_Health_Strategy_Final.pdf (July 12, 2017).

Webster-Stratton, C., Reid, M. J., \& Stoolmiller, M. (2008). Preventing conduct problems and improving school readiness: Evaluation of the Incredible Years Teacher and Child Training Programs in high-risk schools. Journal of Child Psychology and Psychiatry, 49, 471-488. doi: 10.1111/j.1469-7610.2007.01861.x

WHO [World Health Organization] (2001). Mental Health Report 2001. Mental health: New understanding, new hope. Geneva: World Health Organization. Retrieved from http://apps. who.int/iris/bitstream/10665/42390/1/WHR_2001.pdf

WHO [World Health Organization] (2002). Strengthening mental health, resolution of the executive board of the WHO. Retrieved from http://apps.who.int/gb/archive/pdf_files/ EB109/eeb109r8.pdf

WHO [World Health Organization] (2005). Promoting mental health: Concepts, emerging evidence, practice. WHO, Geneva. Retrieved from www.who.int/mental_health/evidence/ MH_Promotion_Book.pdf

Wolfe, T. (2014). The voice of the parent: Perceptions of the United Kingdom Resilience Programme. Educational \& Child Psychology, 31(4), 58-71.

Zimmerman, B. J. (2002). Achieving self-regulation. In F. Pajares \& T. Urdan (Eds.), Academic motivation of adolescents (pp. 175-204). Greenwich, CT, US: Information Age Publishing.

Zimmerman, B. J. (1990). Self-regulated learning and academic achievement: An overview. Educational Psychologist, 25, 3-17.

Zimmerman, B. J., \& Schunk, D. H. (2004). Self-regulating intellectual processes and outcomes: A social cognitive perspective. In D. Y. Dai \& R. J. Sternberg (Eds.), Motivation, emotion, and cognition. Integrative perspectives on intellectual functioning and development (pp. 323349). Mahwah, NJ, US: Lawrence Erlbaum Associates. 